\title{
Pengembangan Karir, Karakteristik dan Kinerja Auditor
}

\author{
Diva Callista Yurianti ${ }^{1}$ \\ Sansaloni Butar Butar ${ }^{2 *}$ \\ ${ }^{1,2}$ Universitas Katolik Soegijapranata \\ *Corresponding author email: sansaloni@ unika.ac.id
}

\begin{abstract}
The auditor profession has an important role in the business world. From time to time, the role of the auditor in increasing the credibility of financial statements is increasingly felt and is needed by users of financial statements. The quality of financial reports is expectedly influenced by audit quality. Therefore, research on the characteristics of auditors is very important to understand the factors that affect auditor performance. This study examines the effect of career development and auditor characteristics on auditor performance. The characteristics of auditors examined are focused on auditor independence, organizational commitment, integrity, confidentiality, and motivation. The test of hypothesis is conducted by using multiple regression analysis. The sample is 64 auditors who work in public accounting firms in Semarang. The results show that career development, organizational commitment, confidentiality, and motivation have a positive effect on auditor performance. Meanwhile, auditor independence and integrity have no effect on auditor performance.
\end{abstract}

Keywords: career development, auditor independence, audit quality, organizational commitment, auditor performance.

\begin{abstract}
Abstrak
Profesi auditor memiliki peran yang penting dalam dunia bisnis. Dari waktu ke waktu peran auditor dalam meningkatkan kredibilitas laporan keuangan semakin terasa dan sangat dibutuhkan oleh pengguna laporan keuangan. Kualitas laporan keuangan dapat dipengaruhi oleh kualitas audit. Karena itu, penelitian tentang karakteristik auditor sangat penting untuk memahami faktor-faktor yang mempengaruhi kinerja auditor. Penelitian ini menguji pengaruh pengembangan karis dan karakteristik auditor terjadap kinerja auditor. Karakteristik auditor yang menjadi fokus penelitian adalah independensi auditor, komitmen organisasi, integritas, kerahasiaan, dan motivasi. Pengujian hipotesis dilakukan dengan analisis regresi berganda menggunakan 64 auditor yang bekerja di Kantor Akuntan Publik yang ada di Semarang sebagai sampel. Hasil analisis menunjukkan bahwa pengembangan karir, komitmen organisasi, kerahasiaan, dan motivasi berpengaruh positif terhadap kinerja auditor. Sedangkan independensi auditor dan integritas tidak berpengaruh terhadap kinerja auditor.
\end{abstract}

Kata Kunci: pengembangan karir, independensi auditor, kualitas audit, komitmen organisasional, kinerja auditor.

\section{PENDAHULUAN}

Kantor Akuntan Publik (KAP) menyediakan jasa audit operasional, audit kepatuhan, dan audit laporan keuangan (Santoso, 2013). Dalam mengerjakan tugasnya, seorang auditor harus bersikap profesional dan selalu berpedoman kepada Kode Etik Akuntan Indonesia. 
Pemeriksaan yang dilakukan oleh auditor akan menambah kredibilitas laporan keuangan sehingga menjadi dasar yang kuat bagi pengguna laporan keuangan dalam menilai kinerja perusahaan yang sesungguhnya. Produk akhir seorang auditor adalah opini audit yang memberikan gambaran tentang kewajaran laporan keuangan tersebut. Opini tersebut digunakan sebagai dasar dalam pengambilan keputusan investasi.

Kinerja adalah hasil kerja seseorang berdasarkan kesungguhan, waktu, pengalaman, dan kecakapan dalam menyelesaikan pekerjaannya (Gustia, 2014). Kinerja seorang auditor dapat dinilai dari konsistensi dalam menerapkan prosedur-prosedur audit yang telah ditetapkan oleh badan otoritas akuntan publik. Menurut Sitio dan Indah (2014) auditor harus melaksanakan tugasnya sesuai dengan tanggung jawab yang telah diberikan. Auditor harus peka terhadap salah saji material karena laporan keuangan yang sudah diaudit akan digunakan pihak-pihak yang berkepentingan dalam mengambil keputusan.

Dalam menjalankan tugasnya, seorang auditor harus menjaga sikap independen (Nuraini, 2016). Auditor melaksanakan pekerjaannya untuk kepentingan umum sehingga tidak boleh memihak kepentingan pihak tertentu. Auditor yang menjalankan tugasnya tanpa keberpihakan dan mampu mempertahankan sikap independen selama penugasan, tidak akan mudah terpengaruh oleh berbagai hal yang dapat mengganggu auditor dalam mempertimbangkan fakta saat melakukan pemeriksaan (Nuraini, 2016). Apabila auditor tidak bersikap independen dalam menilai kredibilitas laporan keuangan, maka kepercayaan pengguna laporan keuangan atas keandalan laporan keuangan dalam merepresentasikan realitas ekonomik perusahaan akan hilang. Oleh karena itu, independensi merupakan atribut penting yang harus dimiliki auditor untuk meningkatkan kepercayaan masyarakat (Gita dan Dwirandra, 2018).

Selain independensi, hal penting lain yang perlu dimiliki auditor adalah komitmen organisasional (Widyaningrum, 2013). Auditor yang memiliki komitmen organisasional akan merasa bahwa ia harus mempertahankan keanggotaan dalam organisasionalnya sehingga auditor tersebut akan melaksanakan tugas yang diberikan dengan baik (Wijaya, 2018). Menurut Putri (2015), komitmen organisasional adalah keadaan dimana seorang pegawai memihak perusahaan dalam bentuk loyalitas serta pencapaian visi dan misi untuk mewujudkan tujuan perusahaan.

Seorang auditor juga harus memiliki integritas yang tinggi karena integritas merupakan sikap jujur, tegas, dan patuh terhadap nilai-nilai moral (Utami, 2015). Auditor yang berintegritas, akan dipercaya oleh masyarakat dan dianggap memiliki kewibawaan dan kejujuran dalam mengerjakan tugasnya (Utami, 2015). Menurut Oktavia (2018), integritas dalam diri auditor menimbulkan kepercayaan pengguna laporan keuangan karena keputusan yang diberikan auditor dapat dipertanggungjawabkan dengan baik dan kinerja auditor akan meningkat.

Faktor lain yang juga perlu dipertimbangkan auditor saat melakukan tugas pengauditan adalah menjaga kerahasiaan informasi tentang klien yang diperoleh selama audit (Prameswari, 2015). Sikap untuk menjunjung tinggi kerahasiaan membuat auditor menghargai nilai dan informasi yang diperoleh sehingga tidak mudah mengungkapkan informasi tersebut (Oktavia (2018). Auditor akan mendapatkan kepercayaan dari klien atau pengguna jasanya jika dapat menyimpan informasi yang diperoleh dengan baik. Menurut Utami (2015) dengan menjaga kerahasiaan klien, auditor telah dianggap bekerja dengan profesional sehingga menghasilkan keputusan audit yang berkualitas (Ariani dan Badera, 2015). 
Hal penting lain yang dapat mempengaruhi kinerja auditor adalah motivasi (Widyaningrum, 2013). Motivasi adalah keinginan seseorang untuk melakukan kegiatan tertentu agar tujuannya dapat tercapai (Umbara, 2017). Jika auditor memiliki motivasi untuk bekerja, dia akan bekerja dengan baik untuk mewujudkan tujuan organisasionalnya. Sebaliknya, jika auditor tidak memiliki motivasi yang dapat mendorongnya untuk bekerja lebih baik maka kinerjanya akan menurun dan tujuan organisasional akan sulit untuk terwujud. Penelitian terdahulu menunjukkan bahwa motivasi yang dimiliki auditor pada saat melakukan penugasan audit dapat meningkatkan kinerja auditor (Temaja dan Utama, 2013). Auditor yang memiliki motivasi tinggi akan menjalankan pekerjaan dengan baik sehingga menghasilkan keputusan audit yang berkualitas.

Penelitian ini menguji kembali faktor-faktor yang mempengaruhi kinerja auditor dengan menambahkan satu variabel independen yaitu pengembangan karir. Pengembangan karir merupakan suatu kesempatan atau peluang yang diberikan kepada karyawan untuk meningkatkan karirnya di suatu organisasional (Fratiwi, 2015). Pengembangan karir karyawan dapat berpengaruh terhadap perusahaan karena dengan adanya pengembangan karir yang diberikan kepada karyawan berarti ada rencana organisasional yang jelas dan moral pegawainya akan lebih terjamin. Dalam KAP terdapat 4 hierarki auditor yaitu partner (rekan) dengan jabatan tertinggi sebagai pemilik, lalu manajer di tingkat kedua sebagai pengawas, lalu auditor senior di tingkat ketiga dengan tugas melaksanakan audit, dan yang terakhir adalah auditor junior dengan tugas melaksanakan prosedur audit dengan rinci. Pengembangan karir yang diberikan kepada individu di suatu perusahaan akan membuat individu tersebut mendapatkan hak yang lebih baik dari sebelumnya seperti pendapatan yang lebih tinggi, fasilitas yang lebih baik, dan posisi di organisasional yang lebih tinggi dari sebelumnya sehingga karyawan yang mendapatkan kesempatan untuk mengembangkan karir akan terdorong juga untuk meningkatkan kinerjanya (Amri et al, 2014).

\section{TINJAUAN LITERATUR DAN PERUMUSAN HIPOTESIS}

\section{Teori Hierarki Kebutuhan}

Abraham Harold Maslow merupakan pelopor aliran psikologi humanistik dan mengemukakan sebuah teori yang dinamakan Teori Hierarki Kebutuhan atau Hierarchy of Needs. Maslow mengembangkan teori motivasi manusia yang tersusun dalam bentuk hierarki, dimana manusia hanya dapat memenuhi setiap hierarki kebutuhannya jika hierarki sebelumnya telah terpuaskan. Kebutuhan-kebutuhan tersebut saling berhubungan, jadi seseorang dapat termotivasi oleh dua kebutuhan atau lebih. Dalam teori yang dikemukakan Maslow, terdapat dua jenjang kebutuhan, yaitu: kebutuhan karena kekurangan (Basic Needs) dan kebutuhan berkembang (meta needs).

Jenjang kebutuhan manusia yang disebabkan oleh kekurangan (basic needs) terdiri dari kebutuhan fisiologi (psychological needs) yang artinya adalah kebutuhan manusia akan sandang, pangan, dan kesehatan. Kemudian yang kedua adalah kebutuhan manusia akan rasa aman (safety needs) yang maksudnya adalah manusia membutuhkan adanya rasa aman, keselamatan, dan bebas dari rasa cemas atau takut. Kebutuhan yang ketiga adalah kebutuhan akan rasa memiliki (belonging needs) yaitu kebutuhan manusia untuk memiliki rasa kasih sayang, rasa sosial dan dapat menjadi bagian dari sebuah kelompok atau masyarakat. Dalam hidup, manusia juga memerlukan kebutuhan atas adanya penghargaan (esteem needs). Kebutuhan akan penghargaan maksudnya adalah kebutuhan manusia untuk memiliki 
kekuatan, kompetensi, kemandirian, dan kepercayaan diri. Serta untuk mendapatkan sebuah penghargaan dari kerja keras yang sudah dilakukan (ketenaran, kesempatan promosi, apresiasi, pengembangan karir, status)

Kebutuhan manusia untuk berkembang (meta needs) terdiri dari kebutuhan aktualisasi diri (self actualization needs) yang maksudnya adalah kebutuhan manusia untuk memaksimalkan kemampuan dan keahlian yang dimiliki, kebutuhan untuk memiliki kreatifitas, pengembangan diri, realisasi diri. Kebutuhan aktualisasi diri juga merupakan kebutuhan manusia untuk memiliki motivasi untuk mencapai suatu tujuan.

Menurut Iskandar (2016), teori ini menjelaskan tentang hubungan antara kebutuhan manusia akan penghargaan dan kinerja karena orang yang mendapatkan penghargaan akan berpikir untuk bekerja lebih produktif. Kebutuhan aktualisasi diri dapat terpenuhi dengan cara meningkatkan motivasi, meningkatkan kreativitas dan kemampuan diri saat bekerja sehingga dapat menghasilkan kinerja yang baik dan dapat mencapai tujuan yang telah ditetapkan. Begitu pula dengan profesi auditor, jika auditor mendapatkan kesempatan untuk mengembangkan karirnya di KAP maka auditor dapat meningkatkan kinerjanya dan memiliki motivasi yang lebih besar untuk mencapai tujuan yang telah ditentukan.

Pengembangan karir adalah suatu proses yang diberikan organisasional kepada individu untuk dapat meningkatkan produktivitasnya dan dapat mencapai suatu posisi yang lebih tinggi di organisasional (Amri et al, 2014). Pengembangan karir membuat seseorang dapat meningkatkan kontribusinya kepada perusahaan (Subashini, 2019). Organisasional memberikan kesempatan karyawannya untuk mengembangkan karir mereka agar dapat meningkatkan semangat kerjanya, dapat memperkuat hubungan karyawan dengan perusahaan atau organisasional tempatnya bekerja, serta dapat meningkatkan kinerja karyawan di organisasional tersebut.

Pengembangan karir diberikan kepada individu yang memenuhi kriteria yang berlaku. Kriteria tersebut adalah senioritas, prestasi kerja, tingkat loyalitas, kejujuran, keluwesan. Dengan adanya pengembangan karir yang diberikan oleh organisasional, karyawan akan meningkatkan disiplin kerjanya, meningkatkan produktivitas kerja dan menghasilkan kinerja yang baik. Pengembangan karir yang diberikan kepada karyawan secara tidak langsung juga akan berpengaruh terhadap organisasional itu sendiri karena karyawan akan berusaha untuk mendapatkan kesempatan untuk mengembangkan karirnya dengan cara bekerja dengan lebih baik dan menghasilkan kinerja yang baik. Seseorang bisa mendapatkan kesempatan untuk mengembangkan karirnya karena ia memiliki kejujuran dalam melakukan pekerjaannya, dapat berkomunikasi dengan baik dengan rekan kerjanya, memiliki loyalitas yang tinggi terhadap organisasionalnya, memiliki inisiatif dan kreatifitas sehingga dapat menyelesaikan pekerjaan yang diberikan dengan tepat waktu, dan memiliki tanggung jawab yang besar terhadap pekerjaannya.

\section{Pengembangan Karir dan Kinerja Auditor}

Dalam sebuah organisasional terdapat beberapa tingkatan jabatan dengan tugas dan tanggung jawabnya masing-masing. Seorang karyawan dapat berpindah ke jabatan yang lebih tinggi dengan adanya pengembangan karir. Pengembangan karir diberikan secara adil kepada individu sesuai dengan kriteria yang telah ditentukan organisasional seperti tingkat senioritas atau lama waktu bekerja dan juga mutu pekerjaan yang dihasilkan oleh individu tersebut. Dengan adanya pengembangan karir yang diberikan, karyawan akan merasa bahwa mereka mendapatkan feedback atas kerja kerasnya selama di organisasional tersebut. 
Hal ini juga berlaku untuk auditor yang bekerja di KAP. Dalam KAP terdapat empat tingkatan jabatan yaitu auditor junior, auditor senior, manajer, dan pemilik. Dengan adanya pengembangan karir yang diberikan kepada auditor, akan muncul semangat kerja dalam diri auditor dan auditor akan meningkatkan kontribusi dan produktivitasnya dalam KAP, sehingga ia akan bekerja dengan lebih baik dan menghasilkan kinerja yang baik pula. Secara tidak langsung, kualitas KAP tersebut juga akan meningkat karena auditornya memiliki kinerja yang baik.

Menurut Subashini (2019) pengembangan karir yang diberikan kepada karyawan akan meningkatkan kontribusi karyawan di organisasional tempatnya bekerja. Karyawan tersebut juga akan memiliki hubungan yang baik dengan pekerja lainnya, memiliki planning atau target yang lebih meyakinkan di organisasional tersebut, dan berupaya bekerja sebaik mungkin untuk meningkatkan kinerjanya. Sementara Lee dan Yunsoo (2018) mengatakan bahwa kesempatan yang diberikan perusahaan untuk pengembangan karir membuat pekerja merasa bahwa organisasional memberikan dukungan atau feedback terhadap pekerjanya sehingga mereka akan bekerja dengan lebih baik lagi dan menghasilkan kinerja yang baik.

Dari uraian di atas maka dapat dirumuskan hipotesis penelitian yang menghubungkan pengembangan karir dan kinerja auditor sebagai berikut:

\section{H1: Pengembangan karir berpengaruh positif terhadap kinerja auditor}

\section{Independensi Auditor dan Kinerja Auditor}

Dalam memberikan jasanya untuk memeriksa laporan keuangan, auditor harus menerapkan independensi. Laporan keuangan suatu perusahaan harus menyajikan informasi yang sesuai dengan keadaan entitas sesungguhnya karena akan membantu investor untuk mengambil keputusan bisnis. Persepsi investor terhadap laporan keuangan dapat dipengaruhi oleh independensi auditor yang mengaudit, walaupun laporan keuangan telah dibuat berdasarkan kebijakan yang benar. Menurut Standar Profesional Akuntan Publik seorang auditor harus bersikap jujur dan memiliki independensi dalam berprofesi agar dapat menghasilkan opini audit yang sesuai dengan keadaan entitas yang sebenarnya dan tanpa ada pengaruh dari klien. Jika auditor tidak memiliki sikap independen, maka hasil pemeriksaan auditor hanya akan mengikuti keinginan dan kepentingan klien.

Terkadang klien juga akan berusaha membangun ikatan atau hubungan kepentingan dengan auditor. Hal tersebut juga akan berdampak terhadap laporan keuangan yang diperiksa karena jika auditor tidak memiliki sikap independen maka auditor dapat melakukan pemeriksaan secara tidak jujur dan telah melanggar kode etik yang berlaku. Tetapi jika auditor memiliki sikap independen dalam bekerja, ia akan bersikap jujur jika menemukan kesalahan saat melakukan pemeriksaan, tidak akan terpengaruh oleh pihak manapun, dan akan melakukan pemeriksaan sesuai dengan kode etik yang berlaku. Sehingga hasil pemeriksaan akan sesuai dengan fakta yang ada dan dapat dikatakan bahwa auditor tersebut memiliki kinerja yang baik. Menurut Hariyanti (2018), jika auditor memiliki sikap independensi maka ia akan mendapat kepercayaan dari pengguna laporan keuangan.

Dari uraian di atas maka dapat dirumuskan hipotesis penelitian yang menghubungkan independensi dan kinerja auditor sebagai berikut:

\section{H2: Independensi Auditor berpengaruh positif terhadap kinerja auditor}




\section{Komitmen Organisasional dan Kinerja Auditor}

Orang yang memiliki komitmen organisasional akan selalu berusaha untuk berpartisipasi dan berperan dalam kegiatan organisasional sehingga dapat menciptakan kerja sama yang baik dengan rekan kerjanya dan akan membantu organisasional untuk mencapai tujuannya. Individu yang memiliki komitmen organisasional akan memiliki ikatan emosional terhadap organisasionalnya yaitu akan menerima nilai-nilai yang ada di organisasional, memberikan dukungan moral terhadap organisasional dan anggotanya, dan akan mengabdi kepada organisasional tempatnya bekerja (Novatiani dan Taofik, 2014). Komitmen organisasional mencerminkan tanggung jawab seseorang. Jika orang tersebut memiliki komitmen organisasional yang rendah, dapat tercermin bahwa orang tersebut memiliki tanggung jawab yang rendah juga terhadap pekerjaannya. Komitmen organisasional dapat merefleksikan loyalitas seseorang terhadap organisasionalnya dan orang tersebut akan selalu memperhatikan organisasionalnya agar dapat membantu mewujudkan tujuan organisasional, ia juga akan merasa senang dan aman jika berada di dalam organisasional tempatnya bekerja.

Seorang auditor yang memiliki komitmen organisasional terhadap KAPnya akan selalu berusaha setia dengan KAP tersebut karena ia merasa diterima di tempatnya bekerja. Auditor tersebut akan bekerja keras dan menghasilkan kinerja yang baik demi keberhasilan dan pencapaian KAP tempatnya bekerja, serta dia merasa bahwa dia harus tetap bertahan pada KAP tersebut. Komitmen organisasional akan memberikan dorongan kepada auditor untuk bertanggung jawab atas tugas yang diberikan dan bekerja lebih baik lagi sehingga kinerja auditor tersebut akan meningkat. Seseorang yang memiliki komitmen organisasional akan berusaha untuk bekerja dengan baik dan meningkatkan kinerjanya serta membantu untuk mewujudkan tujuan organisasional (Putri, 2018).

Dari uraian di atas maka dapat dirumuskan hipotesis penelitian yang menghubungkan komitmen organisasional dan kinerja auditor sebagai berikut:

\section{H3: Komitmen organisasional berpengaruh positif terhadap kinerja auditor}

\section{Integritas dan Kinerja Auditor}

Auditor harus memiliki sikap integritas dalam melakukan tugasnya karena integritas termasuk kualitas yang mendasari kepercayaan publik yaitu klien dan pengguna jasa auditor dalam menguji semua keputusan yang diambil dan integritas mengharuskan auditor untuk bersikap jujur dan bijaksana saat melakukan pemeriksaan laporan keuangan. Jika auditor tidak memiliki sikap integritas dalam bekerja, maka dapat menimbulkan perilaku permisif yaitu perilaku yang serba membolehkan atau mengizinkan segala-galanya. Jika perilaku permisif ini muncul, maka dapat berpengaruh terhadap opini audit yang dihasilkan oleh auditor karena auditor akan cenderung memiliki sikap tidak peduli terhadap kode etik yang berlaku, auditor akan memperbolehkan klien untuk melakukan kecurangan seperti mempengaruhi auditor agar tidak melakukan pemeriksaan dengan cara memberi suap atau menjalin hubungan untuk kepentingan pribadi dengan auditor. Kecurangan yang terjadi akan menyebabkan informasi yang ada di dalam laporan keuangan tidak relevan dan berakibat terhadap pengambilan keputusan yang bias atau keliru. Auditor juga telah melanggar kode etik yang berlaku dan kepercayaan publik serta pengguna laporan keuangan kepada auditor akan hilang.

Integritas mewajibkan auditor untuk jujur dan berterus terang tanpa harus mengorbankan rahasia klien baik itu rahasia informasi pribadi klien maupun rahasia informasi perusahaan yang di audit, serta tidak boleh mengorbankan kepercayaan klien demi kepentingan pribadi 
auditor. Dalam melakukan pemeriksaan laporan keuangan klien, auditor harus bersikap jujur, bertanggung jawab, dan bijaksana dalam mengambil keputusan audit agar klien percaya dengan auditor tersebut serta laporan yang dihasilkan sesuai fakta dan relevan, sehingga dapat meningkatkan kinerja auditor. Kode Etik Profesi Akuntan Publik 120.13-A menjelaskan bahwa auditor harus mengumpulkan bukti audit dan meminta keterangan tentang informasi yang tidak konsisten agar dapat membuat keputusan yang sesuai dengan informasi dan bukti audit yang benar. Jika auditor dapat menerapkan sikap integritas saat bekerja maka kinerja yang dihasilkan auditor akan meningkat.

Dalam Kode Etik Profesi Akuntan Publik Subseksi 111 P111.2 dijelaskan bahwa saat melakukan pemeriksaan auditor tidak boleh mempercayai laporan yang informasinya sengaja tidak diungkapkan atau dihilangkan. Auditor juga tidak boleh mempercayai informasi yang mengandung pernyataan yang tidak dibuat dengan kehati-hatian dan mengandung pernyataan yang menyesatkan. Jika auditor percaya dengan informasi atau laporan yang isinya menyesatkan dan memberikan opini audit berdasarkan pernyataan yang telah disebutkan, maka dapat berpengaruh terhadap keputusan yang diambil oleh perusahaan atau investor. Keputusan perusahaan bisa menjadi bias karena opini audit yang diberikan oleh auditor berdasarkan oleh informasi yang keliru dan tidak dapat dipertanggungjawabkan.

Dari uraian di atas maka dapat dirumuskan hipotesis penelitian yang menghubungkan integritas dan kinerja auditor sebagai berikut:

\section{H4: Integritas berpengaruh positif terhadap kinerja auditor}

\section{Kerahasiaan dan Kinerja Auditor}

Setiap auditor harus menghormati kerahasiaan informasi klien yang diperoleh selama melakukan pemeriksaan audit dan tidak boleh mengungkapkan informasi tersebut tanpa persetujuan pihak yang terkait dan hukum yang berlaku. Informasi klien dapat diungkapkan jika pengungkapan tersebut dilakukan untuk memberikan bukti kepada pihak berwajib dalam suatu proses hukum dan jika ada permintaan atau investigasi dari Ikatan Akuntan Indonesia (IAI). Informasi yang dimaksud merupakan informasi pribadi klien dan informasi perusahaan. Auditor harus menjaga semua kerahasiaan informasi objek pemeriksaan yang di dapat karena jika auditor membocorkan informasi tersebut maka ia telah melanggar kode etik yang berlaku.

Walaupun auditor mungkin menghadapi tekanan dari pihak lain yang mengetahui informasi tersebut, auditor tetap harus menjaga kerahasiaan klien agar dapat dipercaya oleh kliennya. Tekanan-tekanan untuk auditor bisa berasal dari rekan bisnis klien atau perusahaan lain dan terkait dengan informasi klien, masalah strategi bisnis klien atau kondisi keuangan klien. Selain dilihat dari kualitas kerja yang dihasilkan, kinerja auditor yang baik juga dapat dilihat dari keamanahan auditor tersebut dalam menjaga rahasia kliennya (Yendrawati dan Narastuti, 2014). Auditor biasanya merahasiakan pemeriksaannya dari pihak yang bersangkutan agar tidak ada manipulasi atau kecurangan terhadap laporan keuangan yang diperiksa. Menurut Kode Etik Profesi Akuntan Publik Subseksi 114 P114.2, saat hubungan antara auditor dengan klien atau auditor dengan KAP tempatnya bekerja telah berakhir, ia harus tetap menjaga kerahasiaan yang diperoleh dan tidak boleh menggunakan informasi tersebut untuk kepentingan pribadi.

Jika auditor dapat mempertahankan kerahasiaan informasi yang didapatkan dari klien atau pengguna jasa selama tugasnya, dapat dikatakan bahwa auditor tersebut mampu menjalankan pekerjaannya sesuai dengan kode etik yang berlaku. Auditor tersebut juga akan 
menunjukan bahwa ia menjalankan sikap yang profesional, sehingga auditor tersebut dapat menghasilkan pekerjaan yang memuaskan dan dapat meningkatkan kinerjanya.

Dari uraian di atas maka dapat dirumuskan hipotesis penelitian yang menghubungkan kerahasiaan dan kinerja auditor sebagai berikut:

\section{H5 : Kerahasiaan berpengaruh positif terhadap kinerja auditor}

\section{Motivasi dan Kinerja Auditor}

Di dalam sebuah organisasional, karyawan yang bekerja harus diberi arahan dan dorongan agar kemampuan yang mereka miliki dapat berkembang dan dapat memberikan keuntungan bagi organisasional tersebut. Dengan adanya motivasi dalam melakukan pekerjaannya, auditor akan memiliki ketekunan dan kesediaan diri untuk bekerja dengan baik sehingga tujuan organisasional dapat tercapai. Standar Profesional Akuntan Publik menyatakan bahwa motivasi kerja merupakan hal yang harus dimiliki auditor agar dapat memenuhi persyaratan sebagai orang yang profesional. Menurut Chrisnanda (2017) kinerja seseorang berkaitan dengan dua hal yaitu kesediaan diri individu untuk bekerja dan motivasi yang dimiliki individu tersebut. Dua hal tersebut akan menimbulkan usaha individu untuk melakukan pekerjaannya.

Menurut Widyaningrum (2013), auditor yang memiliki motivasi dalam mengerjakan tugasnya akan mendapatkan dorongan yang dapat menggerakkan dan mengendalikan sikapnya dalam melakukan tugas yang diberikan. Saat auditor membuat laporan audit dan melakukan kesalahan saat penyusunan laporan, jika auditor memiliki motivasi dalam bekerja maka ia akan langsung memperbaiki kesalahan yang terjadi. Auditor akan memiliki kemauan dan semangat untuk melakukan pekerjaannya agar mendapatkan hasil yang baik dan dapat meningkatkan kinerjanya. Auditor juga akan memiliki keinginan untuk dapat membantu KAP tempatnya bekerja agar tujuan organisasional lebih mudah tercapai.

Dari uraian di atas maka dapat dirumuskan hipotesis penelitian yang menghubungkan motivasi dan kinerja auditor sebagai berikut:

\section{H6: Motivasi berpengaruh positif terhadap kinerja auditor}

\section{METODE PENELITIAN}

\section{Populasi dan Sampel}

Populasi dalam penelitian ini yaitu seluruh auditor yang bekerja di Kantor Akuntan Publik di Semarang. Penelitian ini menggunakan teknik pengambilan sampel purposive sampling. Purposive sampling adalah teknik pengambilan sampel yang kriterianya ditentukan oleh peneliti sesuai dengan tujuan penelitian. Kriteria pengambilan sampel (responden) adalah auditor yang bekerja di KAP Semarang dan auditor yang bersedia untuk mengisi kuesioner. Berdasarkan kriteria tersebut jumlah responden yang dapat digunakan dalam pengujian hipotesis berjumlah 64 orang dari 12 KAP yang ada di kota Semarang. 


\section{Definisi dan Pengukuran Variabel}

\section{Kinerja Auditor}

Dalam penelitian ini, kinerja auditor merupakan persepsi responden atas hasil kerja mereka terhadap organisasional dalam waktu tertentu. Instrumen yang digunakan terdiri dari 4 item diambil dari Arini (2014), yaitu penyusunan rencana dan program audit, pelaksanaan audit, kesesuaian pelaksanaan audit sesuai dengan standar audit, kuantitas pekerjaan. Kuesioner menggunakan skala likert dengan skala (1) sangat tidak setuju, (2) tidak setuju, (3) netral, (4) setuju, (5) sangat setuju. Responden akan menjawab pertanyaan yang memungkinkan mereka melaporkan reaksi mereka pada pekerjaan mereka. Semakin tinggi skor yang diperoleh maka semakin tinggi pula kinerja auditor.

\section{Pengembangan Karir}

Pengembangan karir dalam penelitian ini merupakan persepsi responden tentang pengembangan karir yang diberikan oleh organisasional. Dalam penelitian ini, pengembangan karir diukur dari delapan item pernyataan yang diambil dari Trisnaningsih (2013), Isti'adah (2014), Umam (2015), dan Rachmantika (2015) yang dimodifikasi. Kuesioner menggunakan skala likert dengan skala (1) sangat tidak setuju, (2) tidak setuju, (3) netral, (4) setuju, (5) sangat setuju. Semakin tinggi skor yang diperoleh maka semakin tinggi pula kesempatan pengembangan karir dalam organisasional.

\section{Independensi Auditor}

Independensi pada penelitian ini adalah dasar kepercayaan masyarakat pada profesi akuntan publik. Dalam penelitian ini, independensi auditor diukur dengan 11 item pernyataan yang diambil dari Widyaningrum (2013). Kuesioner menggunakan skala likert dengan skala (1) sangat tidak setuju, (2) tidak setuju, (3) netral, (4) setuju, (5) sangat setuju. Semakin tinggi skor yang diperoleh maka semakin tinggi pula independensi auditor.

\section{Komitmen Organisasional}

Komitmen organisasional pada penelitian ini merupakan persepsi responden tentang keinginan untuk memelihara keanggotaannya dalam organisasional. Dalam penelitian ini, komitmen organisasional diukur dengan 7 pernyataan yang diambil dari Widyaningrum (2013). Kuesioner menggunakan skala likert dengan skala (1) sangat tidak setuju, (2) tidak setuju, (3) netral, (4) setuju, (5) sangat setuju. Semakin tinggi skor yang diperoleh maka semakin tinggi pula komitmen organisasional.

\section{Integritas}

Integritas dalam penelitian ini adalah sikap kejujuran, keberanian, kebijaksanaan, dan sikap bertanggung jawab yang dimiliki oleh auditor. Dalam penelitian ini, integritas diukur menggunakan 4 item yang diambil dari Arini (2014) yaitu kejujuran auditor, keberanian auditor, sikap bijaksana auditor, dan tanggung jawab auditor. Kuesioner menggunakan skala likert dengan skala (1) sangat tidak setuju, (2) tidak setuju, (3) netral, (4) setuju, (5) sangat setuju. Semakin tinggi skor yang diperoleh maka semakin tinggi pula integritas auditor. 


\section{Kerahasiaan}

Kerahasiaan dalam penelitian ini adalah sikap auditor untuk menghargai informasi yang didapatkan dengan tidak mengungkapkan informasi tersebut kecuali ada hak dan tanggung jawab hukum yang berlaku. Dalam penelitian ini, kerahasiaan diukur menggunakan 2 item yang diambil dari Oktavia (2018) yaitu kehati - hatian atas informasi yang diperoleh auditor serta penggunaan dan pengungkapan informasi. Kuesioner menggunakan skala likert dengan skala (1) sangat tidak setuju, (2) tidak setuju, (3) netral, (4) setuju, (5) sangat setuju. Semakin tinggi skor yang diperoleh maka auditor semakin menerapkan kerahasiaan saat bertugas.

\section{Motivasi}

Motivasi pada penelitian ini adalah cara yang dapat mendorong auditor untuk bekerja dengan mengerahkan kemampuan dan keterampilan nya agar tujuan organisasional dapat lebih mudah tercapai. Dalam penelitian ini, motivasi diukur dengan menggunakan 7 item pernyataan yang diambil dari Siregar (2012). Kuesioner menggunakan skala likert dengan skala (1) sangat tidak setuju, (2) tidak setuju, (3) netral, (4) setuju, (5) sangat setuju. Semakin tinggi skor yang diperoleh maka semakin tinggi pula motivasi.

\section{Model Penelitian}

Uji analisis regresi linier berganda bertujuan untuk memprediksi seberapa besar kekuatan pengaruh variabel independen terhadap variabel dependen. Adapun persamaan regresi yang digunakan adalah sebagai berikut:

$$
\mathrm{KNRJ}=\alpha+\beta 1 \mathrm{PKR}+\beta 2 \mathrm{IND}+\beta 3 \mathrm{KOR}+\beta 4 \mathrm{INT}+\beta 5 \mathrm{KRH}+\beta 6 \mathrm{MTV}+\mathrm{e}
$$

Keterangan:

$\begin{array}{ll}\text { KNRJ } & =\text { Kinerja auditor } \\ \alpha & =\text { konstanta } \\ \beta 1-6 & =\text { Koefisien regresi } \\ \text { PKR } & =\text { Pengembangan karir } \\ \text { IND } & =\text { Independensi auditor } \\ \text { KOR } & =\text { Komitmen organisasional } \\ \text { INT } & =\text { Integritas } \\ \text { KRH } & =\text { Kerahasiaan } \\ \text { MTV } & =\text { Motivasi }\end{array}$




\section{HASIL DAN PEMBAHASAN}

\section{Statistik Deskriptif}

Tabel 1 menampilkan statisti deskriptif variabel-variabel utama dalam penelitian ini. Berdasarkan tabel di atas, jawaban responden yang mengisi pernyataan terkait variabel pengembangan karir memiliki nilai rata-rata sebesar 33.09 yang mana termasuk dalam kategori rentang skala tinggi. Hal ini menunjukkan bahwa responden dapat mengembangkan karirnya dengan baik di KAP tempatnya bekerja.

Tabel 1. Statistik Deskriptif

\begin{tabular}{|c|c|c|c|c|c|c|}
\hline & & & & \multicolumn{3}{|c|}{ Rentang Skala } \\
\hline Variabel & $\begin{array}{c}\text { Kisaran } \\
\text { Teoritis }\end{array}$ & $\begin{array}{c}\text { Kisaran } \\
\text { Aktual }\end{array}$ & $\begin{array}{c}\text { Rata-Rata } \\
\text { (Mean) }\end{array}$ & \multicolumn{2}{|c|}{ Rendah } & \multicolumn{2}{|c|}{ Sedang } & Tinggi \\
\hline $\begin{array}{c}\text { Pengembangan } \\
\text { Karir }\end{array}$ & $8-40$ & $21-40$ & 33.09 & $8-18.6$ & $18.7-29.4$ & $29.5-40$ \\
\hline $\begin{array}{c}\text { Independensi } \\
\text { Auditor }\end{array}$ & $11-55$ & $32-55$ & 45.27 & $11-25.6$ & $25.7-40.4$ & $40.5-55$ \\
\hline $\begin{array}{c}\text { Komitmen } \\
\text { Organisasional }\end{array}$ & $7-35$ & $18-35$ & 28.83 & $7-16.3$ & $16.4-18.7$ & $18.8-35$ \\
\hline $\begin{array}{c}\text { Integritas } \\
\text { Kerahasiaan }\end{array}$ & $12-60$ & $36-60$ & 51.45 & $12-28$ & $28.1-44$ & $44.1-60$ \\
\hline Motivasi & $7-25$ & $16-25$ & 22.41 & $5-11.6$ & $11.7-18.4$ & $18.5-25$ \\
\hline Kinerja Auditor & $10-50$ & $31-48$ & 40.83 & $10-23.3$ & $23.4-36.7$ & $36.8-50$ \\
\hline
\end{tabular}

Variabel independensi auditor memiliki nilai rata-rata jawaban sebesar 45.27 yang mana termasuk dalam kategori rentang skala tinggi. Hal ini menunjukkan bahwa responden yang mengisi kuesioner sebagian besar telah bekerja secara jujur dan tidak terdapat campur tangan pihak lain saat bekerja.

Variabel komitmen organisasional memiliki nilai rata-rata jawaban sebesar 28.83 yang mana termasuk dalam kategori rentang skala tinggi. Hal ini menunjukkan bahwa responden yang mengisi kuesioner pada penelitian ini memiliki loyalitas terhadap KAPnya dan akan selalu bekerja dengan baik agar dapat membantu mewujudkan tujuan KAP tempatnya bekerja.

Variabel integritas memiliki nilai rata-rata jawaban sebesar 51.45 yang mana termasuk dalam kategori rentang skala tinggi. Hal ini menunjukkan bahwa auditor yang menjadi responden telah bekerja dengan jujur, bertanggung jawab, dan bijaksana. Integritas yang dimiliki responden juga dapat dikatakan baik karena integritas adalah kualitas yang mendasari kepercayaan klien dalam menguji semua keputusan yang diambil.

Variabel kerahasiaan memiliki nilai rata-rata sebesar 22.41 yang mana termasuk dalam kategori rentang skala tinggi. Hal ini menunjukkan bahwa auditor yang menjadi responden tetap menghormati kerahasiaan informasi klien saat bekerja dan tidak pernah mengungkapkan informasi kliennya untuk kepentingan pribadi. 
Variabel motivasi memiliki nilai rata-rata sebesar sebesar 29.98 yang mana termasuk dalam kategori nilai rentang skala tinggi. Hal ini menunjukkan bahwa auditor yang menjadi responden memiliki dorongan untuk bekerja dengan baik

Variabel kinerja auditor memiliki nilai rata-rata sebesar 40.83 yang mana termasuk dalam kategori nilai rentang skala tinggi. Hal ini menunjukkan bahwa auditor yang menjadi responden telah melakukan tugasnya dengan memperhatikan output yang akan dihasilkan dan dapat melakukan pekerjaannya dengan memperhatikan waktu yang diperlukan untuk menyelesaikan targetnya.

Analisis regresi mensyaratkan bahwa residual memiliki distribusi normal. Selain itu, variabel-variabel yang diuji juga harus menunjukkan bebas heteroskedastisitas, multikolineratisa, dan autokorelasi. Hasil pengujian asumsi-asumsi yang mendasari regresi berganda menunjukkan bahwa data yang digunakan dalam penelitian ini memenuhi asumsi tersebut.

\section{Hasil Penelitian}

Pengujian hipotesis pengaruh variabel pengembangan karir, independensi auditor, komitmen organisasional, integritas, kerahasiaan, dan motivasi terhadap kinerja auditor dalam penelitian ini diuji dengan menggunakan uji regresi. Hasil selengkapnya dapat dilihat pada tabel 2.

\section{Pengembangan Karir}

Berdasarkan hasil pengujian yang dilakukan, diperoleh koefisien beta positif sebesar 0.357 dan hasil signifikansi $0.000<0.05$. Hal tersebut menunjukkan bahwa variabel Pengembangan Karir memiliki pengaruh positif terhadap Kinerja Auditor. Artinya, kesempatan dalam pengembangan karir yang diberikan KAP meningkatkan kinerja auditor. Jadi, $\mathrm{H}_{1}$ diterima.

\section{Independensi Auditor}

Berdasarkan hasil pengujian yang dilakukan, diperoleh koefisien beta positif sebesar 0.061 dan hasil signifikansi $0.107>0.05$. Hal tersebut menunjukkan bahwa variabel Independensi Auditor tidak memiliki pengaruh signifikan terhadap Kinerja Auditor. Jadi, $\mathrm{H}_{2}$ ditolak.

Tabel 2. Hasil Pengujian Hipotesis

\begin{tabular}{|c|c|c|c|c|c|}
\hline \multirow{2}{*}{ Variabel } & \multicolumn{2}{|c|}{$\begin{array}{c}\text { Unstandardized } \\
\text { Coefficients }\end{array}$} & $\mathrm{t}$ & sig. & Hasil \\
\cline { 2 - 6 } & $\mathrm{B}$ & $\begin{array}{c}\text { Std. } \\
\text { Error }\end{array}$ & & & \\
\hline Constant & 6.745 & 2.604 & 2.590 & 0.012 & \\
\hline Pengembangan Karir & 0.357 & 0.054 & 6.639 & 0.000 & Diterima \\
\hline
\end{tabular}


ISSN 1412-775X (media cetak) | 2541-5204 (media online)

\begin{tabular}{|c|c|c|c|c|c|}
\hline $\begin{array}{c}\text { Independensi } \\
\text { Auditor }\end{array}$ & 0.061 & 0.037 & 1.635 & 0.107 & Ditolak \\
\hline $\begin{array}{c}\text { Komitmen } \\
\text { Organisasional }\end{array}$ & 0.323 & 0.071 & 4.560 & 0.000 & Diterima \\
\hline Integritas & -0.041 & 0.032 & -1.293 & 0.201 & Ditolak \\
\hline Kerahasiaan & 0.307 & 0.105 & 2.926 & 0.005 & Diterima \\
\hline Motivasi & 0.197 & 0.065 & 3.038 & 0.004 & Diterima \\
\hline
\end{tabular}

\section{Komitmen Organisasional}

Berdasarkan hasil pengujian yang dilakukan, diperoleh koefisien beta positif sebesar 0.323 dan hasil signifikansi $0.000<0.05$. Hal tersebut menunjukkan bahwa variabel Komitmen Organisasional memiliki pengaruh positif terhadap Kinerja Auditor. Artinya, semakin tinggi loyalitas dan komitmen auditor terhadap KAP tempat dia bekerja maka semakin tinggi pula kinerjanya. Jadi, $\mathrm{H}_{3}$ diterima.

\section{Integritas}

Berdasarkan hasil pengujian yang dilakukan, diperoleh koefisien beta positif sebesar 0.041 dan hasil signifikansi $0.201>0.05$. Hal tersebut menunjukkan bahwa variabel Integritas tidak memiliki pengaruh signifikan terhadap Kinerja Auditor. Jadi, $\mathrm{H}_{4}$ ditolak.

\section{Kerahasiaan}

Berdasarkan hasil pengujian yang dilakukan, diperoleh koefisien beta positif sebesar 0.307 dan hasil signifikansi $0.005<0.05$. Hal tersebut menunjukkan bahwa variabel Kerahasiaan memiliki pengaruh positif terhadap Kinerja Auditor. Ini menunjukkan bahwa bahwa semakin tinggi auditor menerapkan kode etik kerahasiaan dalam menjalankan tugasnya, maka kinerjanya akan semakin meningkat. Jadi, $\mathrm{H}_{5}$ diterima.

\section{Motivasi}

Berdasarkan hasil pengujian yang dilakukan, diperoleh koefisien beta positif sebesar 0.197 dan hasil signifikansi $0.004<0.05$. Hal tersebut menunjukkan bahwa variabel Motivasi memiliki pengaruh positif terhadap Kinerja Auditor. Ini menunjukkan bahwa semakin tinggi motivasi yang dimiliki auditor dalam bekerja, maka semakin tinggi pula kinerjanya. Jadi $\mathrm{H}_{6}$ diterima.

\section{Pembahasan}

Dari hasil pengujian yang telah dilakukan menunjukkan bahwa pengembangan karir berpengaruh positif terhadap kinerja auditor. Pengembangan karir merupakan suatu proses yang diberikan organisasional kepada individu untuk dapat meningkatkan produktivitasnya dan dapat mencapai suatu posisi yang lebih tinggi di organisasional. Dengan adanya pengembangan karir yang diberikan, auditor merasa telah mendapatkan feedback dari kerja keras yang telah dilakukan. Auditor juga akan memberikan lebih banyak kontribusi kepada KAP dan akan menentukan target yang lebih meyakinkan sehingga ia dapat bekerja dengan 
lebih baik. Pengembangan karir yang diberikan tidak hanya memiliki peran positif untuk auditor, tetapi juga berperan positif untuk KAP karena dengan adanya pengembangan karir, kinerja auditor akan meningkat. Dengan meningkatnya kinerja auditor, secara tidak langsung juga akan meningkatkan kualitas KAP. Hasil yang ditemukan konsisten dengan Subashini (2019) dan penelitian Lee dan Yunsoo (2018) yang juga melaporkan bahwa pengembangan karir berpengaruh positif terhadap kinerja auditor.

Pengujian yang telah dilakukan sebelumnya menunjukkan bahwa independensi auditor tidak berpengaruh terhadap kinerja auditor meskipun dalam pengujian statistik deskriptif variabel independensi memiliki nilai rata-rata jawaban dalam rentang skala yang tinggi. Hal ini terjadi karena dalam penelitian ini pengukuran kinerja auditor dilihat melalui waktu pelaksanaan audit, kesesuaian pemeriksaan audit dengan standar audit yang berlaku, serta kuantitas pekerjaan yang dihasilkan. Sedangkan pengukuran independensi auditor dalam penelitian ini lebih terfokus kepada apakah terdapat campur tangan pihak lain saat auditor melaksanakan penugasan. Selain itu, faktor lain yang diduga menjadi sebab hipotesis ini ditolak adalah responden yang kurang konsisten dengan jawaban yang mereka berikan. Contohnya seperti responden nomor 10 , dari 11 pernyataan yang diberikan ia memilih skala nomor 4 atau 5 untuk 10 pernyataan dan memilih skala nomor 2 untuk 1 pernyataan. Ada beberapa responden lain yang melakukan hal yang sama. Sehingga hal tersebut juga diduga sebagai penyebab hipotesis ini ditolak.

Tabulasi kuesioner menunjukkan bahwa terdapat beberapa auditor yang melakukan penugasannya dengan adanya campur tangan pimpinan untuk menentukan, memodifikasi dan mengeliminasi beberapa bagian yang diperiksa. Namun, jika dilihat kembali dalam pengujian statistik deskriptif yang telah dilakukan, auditor yang menjadi responden tetap menjaga sikap profesionalnya dalam melaksanakan tugas dengan berdasar kepada ketelitian dan kesungguhan untuk menghasilkan opini audit yang berkualitas. Hasil penelitian ini sesuai dengan Ananta (2013) dan Triharsanty (2012) yang melaporkan bahwa independensi auditor tidak berpengaruh terhadap kinerja auditor.

Dari hasil pengujian yang telah dilakukan sebelumnya menunjukkan bahwa komitmen organisasional berpengaruh positif terhadap kinerja auditor. Komitmen organisasional yang dimiliki auditor merefleksikan loyalitasnya terhadap KAP tempat ia bekerja, dengan adanya komitmen organisasional dalam diri auditor maka akan timbul rasa memiliki terhadap KAP tempatnya bekerja. Auditor merasa senang bekerja di KAPnya, ia merasa diterima dan telah menjadi bagian dari KAP sehingga ia akan bekerja dengan lebih baik untuk meningkatkan kinerjanya. Auditor juga akan memiliki hubungan yang baik dengan rekan kerjanya sehingga mereka memutuskan untuk menghabiskan karirnya dengan bekerja di KAP tersebut. Hasil penelitian ini sesuai dengan Putri (2015) dan Hariyanti (2018) yang melaporkan bahwa komitmen organisasional berpengaruh positif terhadap kinerja auditor.

Pengujian yang telah dilakukan sebelumnya menunjukkan bahwa integritas tidak berpengaruh terhadap kinerja auditor. Auditor yang menjadi responden telah menjalankan tugasnya dengan jujur, baik, dan bertanggung jawab. Auditor bekerja sesuai dengan peraturan kode etik yang berlaku, bekerja dengan hati-hati, serta selalu mempertimbangkan permasalahan dan akibat-akibatnya dengan seksama. Namun, ada beberapa responden yang setuju dengan pernyataan bahwa auditor tidak perlu mempertimbangkan keadaan individu atau suatu kelompok untuk membenarkan perbuatan yang melanggar peraturan yang berlaku. Artinya, masih banyak auditor yang mewajarkan bahkan membenarkan tindakan seseorang yang melakukan pelanggaran terhadap peraturan yang berlaku dan hal tersebut jelas tidak bisa 
dibenarkan. Output atau opini audit yang dihasilkan akan sulit untuk dipercaya oleh klien atau pengguna laporan keuangan karena auditor tidak bersikap bijaksana dalam bekerja.

Tetapi sebagian besar auditor yang menjadi responden telah memiliki integritas yang baik, hal tersebut dapat dibuktikan dari hasil pengujian statistik deskriptif yang memiliki nilai rata-rata jawaban dalam rentang skala tinggi. Hasil penelitian ini sesuai dengan Prameswari (2015) serta Hapsari (2018) yang melaporkan bahwa integritas tidak berpengaruh terhadap kinerja auditor.

Dari hasil pengujian yang telah dilakukan menunjukkan bahwa kerahasiaan berpengaruh positif terhadap kinerja auditor. Kerahasiaan informasi klien harus dijaga oleh seorang auditor agar mendapat kepercayaan dari publik dan juga karena kerahasiaan termasuk dalam kode etik seorang auditor. Banyak tekanan-tekanan yang didapatkan auditor agar ia mengungkapkan informasi yang diperoleh, namun auditor yang menerapkan kode etik dalam bertugas tidak akan menggunakan informasi-informasi tersebut untuk kepentingan pribadinya, ia hanya dapat mengungkapkan informasi tersebut jika mendapatkan otorisasi yang memadai dan sesuai dengan peraturan perundang-undangan yang berlaku. Auditor yang melakukan hal-hal tersebut saat bertugas dapat dikatakan memiliki profesionalisme yang baik dan kinerjanya akan meningkat. Hasil penelitian ini sesuai dengan Prameswari (2015) serta Yendrawati dan Narastuti (2014) yang melaporkan bahwa kerahasiaan berpengaruh positif terhadap kinerja auditor.

Dari hasil pengujian yang telah dilakukan menunjukan bahwa motivasi berpengaruh positif terhadap kinerja auditor. Motivasi akan mendorong auditor untuk memiliki ketekunan agar kemampuan yang mereka miliki dapat berkembang sehingga mereka akan menghasilkan kinerja yang baik dan dapat membantu mencapai tujuan KAP tempat mereka bekerja. Auditor melakukan tugasnya dengan sikap disiplin dan selalu berusaha untuk bekerja dengan kondisi kerja yang menyenangkan dan baik. Auditor yang memiliki motivasi untuk bekerja akan merasa lebih puas karena dapat menyelesaikan tugas yang dianggap sulit dan menantang. Hasil penelitian ini sesuai dengan Umbara (2017) dan Hariyanti (2018) yang melaporkan bahwa motivasi berpengaruh positif terhadap kinerja auditor.

\section{SIMPULAN}

Berdasarkan penelitian yang telah dilakukan, maka diperoleh kesimpulan sebagai berikut: 1. Pengembangan karir berpengaruh positif terhadap kinerja auditor. Hasil penelitian ini sesuai dengan Subashini (2019) serta penelitian `Lee dan Yunsoo (2018). 2. Independensi auditor tidak berpengaruh terhadap kinerja auditor. Hasil penelitian ini sesuai dengan Ananta (2013) dan Triharsanty (2012). 3. Komitmen organisasional berpengaruh positif terhadap kinerja auditor. Hasil penelitian ini sesuai dengan Putri (2015) dan Hariyanti (2018). 4. Integritas tidak berpengaruh terhadap kinerja auditor. Hasil penelitian ini sesuai dengan Prameswari (2015) serta Hapsari (2018). 5. Kerahasiaan berpengaruh positif terhadap kinerja auditor. Hasil penelitian ini sesuai dengan Prameswari (2015) serta Yendrawati dan Narastuti (2014). 6. Motivasi berpengaruh positif terhadap kinerja auditor. Hasil penelitian ini sesuai dengan Umbara (2017) dan Hariyanti (2018).

Pemeriksaan audit yang dilakukan sebaiknya bebas dari campur tangan orang lain, termasuk supervisor karena dapat mengurangi bahkan menghilangkan sikap independen auditor. Untuk penelitian selanjutnya dapat menambahkan variabel moderasi seperti 
kompetensi, kelebihan peran, atau konflik peran. Menambah jumlah auditor atau responden yang menjadi sampel penelitian.

\section{DAFTAR PUSTAKA}

Adelia, T. 2018. Pengaruh Kompetensi dan Pengalaman Auditor Terhada Pengumpulan Bukti Audit (Survey Pada Kantor Akuntan Publik di Kota Bandung yang Terdaftar di Ikatan Akuntan Publik Indonesia). Retrieved from http://repository.unpas.ac.id/37127/

Amri, W. K. 2014. Pengaruh Kemampuan, Motivasi, dan Pengembangan Karir Terhadap Kinerja Auditor Inspektorat Kabupaten Bengkalis. Jurnal Teknologi Kimia Dan Industri, 2(1), 1-7.

Ananta, A. H. 2013. Pengaruh Independensi Auditor, Komitmen Organisasi, Gaya Kepemimpinan, Budaya Organisasi, Pemahaman Good Governance dan Ketidakjelasan Peran Terhadap Kinerja Auditor.

Ariani, K. G. 2015. Pengaruh Integritas, Obyektifitas, Kerahasiaan, Dan Kompetensi Pada Kinerja Auditor Inspektorat Kota Denpasar. E-Jurnal Akuntansi Universitas Udayana $10.1,1,182-198$.

Chrisnanda, D. 2017. Pengaruh Motivasi Kerja Terhadap Kinerja Karyawan di PT.Mas Sumbiri. 124. Retrieved from https://repository.usd.ac.id/8914/1/122214091_full.pdf

Fransiska, R. M. 2014. Evaluasi Penerapan Pengendalian Intern Atas Prosedur Pemberian Kredit Pada PT Columbindo Perdana Cabang Pemalang. (D Iii), 7-26.

Fratiwi, S. 2015. Perbedaan Peluang Pengembangan Karir di Hotel Grand Zuri Duri Berdasarkan Jenis Kelamin. Retrieved from http://repository.unika.ac.id/17377/

Gita, A. A. N. A. W., dan A. A. N. B. Dwirandra. 2018. Pengaruh Independensi, Integritas, Kompetensi, dan Struktur Audit terhadap Kualitas Audit Kantor

Inspektorat. Retrieved from https://doi.org/10.24843/eja.2018.v25.i02.p08

Gustia, N. 2014. Pengaruh Independensi Auditor, Etika Profesi, Komtimen Organisasi, dan Gaya Kepemimpinan Terhadap Kinerja Auditor Pemerintah (Studi Empiris pada Auditor Pemerintah di BPKP Perwakilan Sumbar). Jurnal Akutansi, 2(1), 45-48.

Hapsari, W. 2018. Pengaruh Independensi Auditor, Komitmen Organisasi, Integritas Auditor, dan Budaya Organisasi Terhadap Kinerja Auditor (Studi Empiris pada Kantor Akuntan Publik di Surakarta dan Yogyakarta). Retrieved: http://eprints.ums.ac.id/58178/13/NASKAH PUBLIKASI.pdf

Akuntan Publik di Daerah Istimewa Yogyakarta. 48(2), 123-154. Retrieved from https://eprints.uny.ac.id/60416/1/SKRIPSI.

Institut Akuntan Publik Indonesia. 2020. Directory 2020 Kantor Akuntan Publik dan Akuntan. Institut Akuntan Publik Indonesia. 2020. Kode Etik Profesi Akuntan Publik. 
Iskandar, I. 2016. Implementasi Teori Hirarki Kebutuhan Abraham Maslow terhadap Peningkatan Kinerja Pustakawan. Khizanah Al-Hikmah: Jurnal Ilmu Perpustakaan, Informasi, Dan Kearsipan, 4(1), 23-34. https://doi.org/10.24252/kah.v4i1a2

Lee, Y., dan J. Y. Lee. 2018. A multilevel analysis of individual and organizational factors that influence the relationship between career development and job performance improvement. European Journal of Training and Development, 42(5-6), 286-304.

Menteri Keuangan. 2008. Peraturan Keputusan Menteri Keuangan (PMK) No. 17/PMK.01/2008. Retrieved from https://jdih.kemenkeu.go.id/fulltext/2008/17 pmk.01 2008per.htm

Mulyadi. 2012. Auditing (Edisi Keenam). Jakarta: Salemba Empat.

Novatiani, R. A., and M. Taofik. 2014. Pengaruh Profesionalisme Auditor Internal dan Komitmen Organisasi Auditor Internal Terhadap Kinerja (Studi Kasus Pada Inspektorat Kabupaten Purwakarta). E-Jurnal Akuntansi Universitas Udayana, 5(978), 104-110.

Nuraini, L. 2016. Pengaruh Independensi, Gaya Kepemimpinan dan Budaya Organisasi Terhadap Kinerja Auditor (Studi Empiris Pada Kantor Akuntan Publik Yogyakarta dan Solo). (August). Retrieved from https://eprints.uny.ac.id/38920/

Oktavia, M. H. 2018. Pengaruh Integritas, Kerahasiaan, Kompleksitas Tugas, Motivasi dan Ketidakjelasan Peran Terhadap Kinerja Auditor di Inspektorat Provinsi Jawa Tengah. 2, 227-249. Retrieved from http://repository.unika.ac.id/17377/

Parwita, G. B. S., I.W.G, S., \& S. Putu, 2014. Pengaruh Kepuasan Kerja Terhadap Komitmen Organisasi dan Disiplin Kerja. E-Jurnal Akuntansi Universitas Udayana, 8.2(3), 91-101. Retrieved from https://media.neliti.com/media/publications/44644-ID-pengaruhkepuasankerja-terhadap-komitmen-organisasi-dan-disiplin-kerja.pdf

Prameswari, D. A. 2015. Pengaruh Penerapan Integritas, Obyektivitas, Kerahasiaan, Kompetensi dan Komitmen Organisasi Terhadap Kinerja Internal Auditor. 2(3), 3229_ 3236.

Putri, H. E. 2018. Pengaruh Profesionalisme dan Komitmen Organisasi Terhadap Kinerja Auditor Internal (Pada BUMN Sektor Industri Pengolahan di Kota Bandung). Retrieved from http://repository.unpas.ac.id/36994/

Putri, Y. M. 2015. Pengaruh Komitmen Organisasi, Profesionalisme, dan Perilaku Etis Terhadap Kinerja Auditor di Kantor Akuntan Publik Wilayah Yogyakarta. 1-158. Retrieved from https://eprints.uny.ac.id/26843/

Rachmantika, S. M. 2015. Pengaruh Evaluasi Pelatihan dan Pengembangan Karir Terhadap Kinerja Pegawai Negeri Sipil Kota Yogyakarta.

Sanjaya, R. 2018. Pengaruh Motivasi Kerja Terhadap Kinerja Pegawai Dalam Perspektif Ekonomi Islam (Studi di Dinas Sosial Tenaga Kerja dan Transmigrasi Kabupaten Pesisir Barat). Retrieved from http://repository.radenintan.ac.id/3563/1/SKRIPSI.pdf 
Santoso, N. S. V. 2013. Pengaruh Konflik Peran, Ketidakjelasan Peran, Kelebihan Peran dan Independensi Auditor Terhadap Kinerja Auditor (Studi Empiris Pada Kantor Akuntan Publik di Semarang). Retrieved from http://repository.unika.ac.id/961/

Siregar, E. M. 2012. Pengaruh Kualitas Sumber Daya Manusia, Komitmen Organisasi, dan Motivasi Kerja Dengan Tindakan Supervisi Sebagai Variabel Moderating Terhadap Kinerja Auditor Pada Inspektorat Provinsi Sumatera Utara.

Sitio, R., dan Indah, A. 2014. Pengaruh Pemahaman Good Governance, Gaya Kepemimpinan, Budaya Organisasi Dan Struktur Audit Terhadap Kinerja Auditor (Studi Empiris Pada Kantor Akuntan Publik Di Kota Semarang). Accounting Analysis Journal, 3(3), 301309.

Subashini, J. K. . N. 2019. Career Development for Performance Enhancement of NonAcademic Staff in Career Development for Performance Enhancement of NonAcademic Staff in Higher Education Institutes. (July). Retrieved from https://www.researchgate.net/publication/333683026_Career_Development_for_Perfor mance_Enhancement_of_NonAcademic_Staff_in_Higher_Education_Institutes

Supriyanto, A. S. 2013. Role of Procedural Justice, Organizational Commitment and Job Satisfaction on job Performance: The Mediating Effects of Organizational Citizenship Behavior. International Journal of Business and Management, 8(15). https://doi.org/10.5539/ijbm.v8n15p57

Triharsanty, F. 2012. Pengaruh Independensi Auditor, Komitmen Organisasi, Gaya Kepemimpinan, Budaya Oranisasi, dan Profesionalisme Auditor Terhadap Kinerja Auditor. Retrieved from http://repository.unika.ac.id/10270/

Tusiana, V. 2018. Pengaruh Independensi, Profesionalisme, Motivasi, Etika Profesi, Pengalaman, dan Locus of Control Terhadap Kinerja Auditor (Studi Empiris pada KAP di Semarang). 2, 227-249. Retrieved from http://repository.unika.ac.id/18809/

Utami, U. I. 2015. Pengaruh integritas, obyektifitas, kerahasian, kompetensi dan pengalaman kerja terhadap kinerja auditor di inspektorat prov Riau.

Widyaningrum, V. 2013. Pengaruh Independensi Auditor, Komitmen Organisasi,Gaya Kepemimpinan, Budaya Organisasi, dan Motivasi Terhadap Kinerja Auditor (Studi Empiris Pada Kantor Akuntan Publik di Semarang). Retrieved from http://repository.unika.ac.id/2436/

Wijaya, A. G. 2018. Pengaruh Big Five Personality, Konflik Peran, Komitmen Organisasi dan Ketidakjelasan Peran Terhadap Kinerja Auditor Eksternal di Kantor Akuntan Publik Wilayah Semarang. 2, 227-249. Retrieved from http://repository.unika.ac.id/16548/

Yendrawati, R., dan Nurwulan, R. N. 2014. Pengaruh Integritas, Obyektivitas, Kerahasiaan, dan Kompetensi Terhadap Kinerja Auditor Pemerintah. 29-35.

Yudha, T. R. K. (2019). Pengaruh Integritas, Objektifitas, Kerahasiaan, dan Kompetensi Auditor Terhadap Kinerja Auditor Internal (Studi Empiris Pada Inspektorat Kabupaten Bandung). https://doi.org/10.22201/fq.18708404e.2004.3.66178 